\title{
Isolated Compounds from Buddleja Coriacea with Antibacterial and Anti-Inflammatory Activities in the Urinary Tract
}

\section{(ㄷ) (1) $($ 우 $\odot$}

\author{
Authors \\ Luis Apaza Ticona1, 2, Francisco Aguilar Rico¹, Javier Sánchez Sánchez-Corral1, Montserrat Ortega Domenech³, \\ Ángel Rumbero Sánchez ${ }^{1}$
}

\section{Affiliations}

1 Department of Organic Chemistry, Faculty of Sciences, University Autónoma of Madrid, Cantoblanco, Madrid, Spain

2 Department of Pharmacology, Pharmacognosy and Botany, Faculty of Pharmacy, University Complutense of Madrid, Madrid, Spain

3 Dr. Goya Análisis, SL, Alcalá de Henares, Madrid, Spain

\section{Key words}

Loganiaceae, Buddleja coriacea, urinary infections, cystitis, antibacterial, anti-inflammatory, secondary metabolites

received 30.08 .2021

revised 10.10 .2021

accepted $\quad 04.11 .2021$

\section{Bibliography}

Planta Med Int Open 2022; 9: e12-e22

DOI 10.1055/a-1696-6851

ISSN 2509-9264

(c) 2022. The Author(s).

This is an open access article published by Thieme under the terms of the Creative Commons Attribution-NonDerivative-NonCommercial-License, permitting copying and reproduction so long as the original work is given appropriate credit. Contents may not be used for commecial purposes, or adapted, remixed, transformed or built upon. (https://creativecommons. org/licenses/by-nc-nd/4.0/)

Georg Thieme Verlag KG, Rüdigerstraße 14,

70469 Stuttgart, Germany

\section{Correspondence}

Prof. Dr. Luis Apaza T.

Department of Organic Chemistry

Faculty of Sciences

University Autónoma of Madrid

Street Francisco Tomás y Valiente, 7

Cantoblanco

28049 Madrid

Spain

Tel.: + 34/91/497 7622, Fax: + 34/91/497 4715

Inapaza@ucm.es; luis.apaza@uam.es $\circledast$ Supplementary material is available under https://doi.org/10.1055/a-1696-6851.

\begin{abstract}
Buddleja coriacea Remy is one of the plant species used by the Bolivian population for the treatment of urinary infections. This study aimed to identify the extract, fractions, and compounds responsible for the antibacterial and anti-inflammatory activities of $B$. coriacea leaves. Bioguided isolation of compounds with antibacterial and anti-inflammatory activities was carried out by measuring the antibacterial effect against specific pathogenic microbial strains, Klebsiella pneumoniae, Proteus mirabilis, Pseudomonas aeruginosa, and Serratia marcescens, and the inhibition of NF- $k$ B in RM-2 and MM.14Ov cells. Bioassay-guided isolation led to the isolation and characterisation of (4aR,4bS, 5 S, 6aS, 6bS,9aR, 10aS, 10bS)-6b-glycoloyl-5-hydroxy-4a,6a-dimethyl-8-propyl-4a,4b,5,6,6a,6b,9a,10,10a,1 0b, 11,12-dodecahydro-2H-naphtho [2', 1':4,5] indeno [1,2-d] [1,3] dioxol-2-one (1), 3-[3-(2-dimethylaminoethyl)-1H-indol5 -yl]-N-(4-methoxybenzyl) acrylamide (2), and $(1 \beta, 11 \beta, 12 \alpha)$ 1,11,12-trihydroxy-11,20-epoxypicrasa-3,13(21)-diene-2,16dione (3) by nuclear magnetic resonance and mass spectroscopy. All compounds showed antibacterial activity with minimum inhibitory concentration values of 11.64-11.81, 0.17-0.19, and $0.34-0.36 \mu \mathrm{M}$, respectively, on the tested strains, while the positive control, ofloxacin, had a minimum inhibitory concentration of $27.66 \mu \mathrm{M}$. Finally, all the compounds showed NF- $\kappa B$ inhibitory activity with $\mathrm{IC}_{50}$ values of $11.25-11.34,0.15-0.16$, and $0.33-0.36 \mu \mathrm{M}$, respectively, in all cell lines, while the positive control, celastrol, had an $\mathrm{IC}_{50}$ of $7.96 \mu \mathrm{M}$. Thus, this study managed to isolate and evaluate for the first time the pharmacological potential of three compounds present in the leaves of $B$. coriacea with antibacterial and anti-inflammatory activities.
\end{abstract}




\begin{tabular}{|c|c|}
\hline AcOEt & ethyl acetate \\
\hline ACT & actinomycin D \\
\hline $\mathrm{CC}_{50}$ & cytotoxic concentration $50 \%$ \\
\hline COPD & chronic obstructive pulmonary disease \\
\hline DCM & dichloromethane \\
\hline $\mathrm{DH}_{2} \mathrm{O}$ & distilled water \\
\hline $\mathrm{Et}_{2} \mathrm{O}$ & diethyl ether \\
\hline HEX & n-hexane \\
\hline IKK $\alpha \beta$ & $\begin{array}{l}\text { suppresses the degradation of } І_{\kappa} \beta \alpha \text { and inhibits } \\
\text { the translocation of p } 65 \text { to the nucleus }\end{array}$ \\
\hline IL-1 $\beta$ & interleukin- $1 \beta$ \\
\hline IL-6 & interleukin-6 \\
\hline $\mathrm{LDH}$ & lactate dehydrogenase \\
\hline LPS & lipopolysaccharides \\
\hline MIC & minimum inhibitory concentration \\
\hline NF-кB & $\begin{array}{l}\text { nuclear factor kappa-light-chain-enhancer of } \\
\text { activated B cells }\end{array}$ \\
\hline QTOF & quadrupole time-of-flight \\
\hline rt & room temperature \\
\hline TLR & Toll-like receptor \\
\hline TMS & tetramethylsilane \\
\hline UTI & urinary tract infection \\
\hline ZI & zone of inhibition \\
\hline
\end{tabular}

\section{Introduction}

The excretory system is fundamental for health, as it is responsible for the elimination of all kinds of unnecessary and detrimental substances and waste. In this context, UTIs are one of the most frequent infections among the adult population [1]. However, the increasing prevalence of antibacterial resistance among common uropathogens requires research on new therapeutic treatments [2] given that UTIs are diseases caused by pathogens, predominantly bacteria (such as Escherichia coli, Staphylococcus aureus, and Klebsiella pneumoniae) [3].

Infections begin with periurethral contamination of a pathogen that resides in the intestine that is followed by the pathogen's colonisation of the urethra and bladder. In the bladder, pathogens proliferate and can ascend to the kidneys and reach the vascular system, triggering more serious problems [4]. In this sense, TLRs trigger inflammatory reactions and bind primarily to LPS found in gram-negative bacteria [5], generating bacterial resistance and the chronicity of the disease. The chronicity of the disease implies that the inflammatory response can be prolonged over time, damaging the bladder and mucous membranes, which is detrimental to the patient's life quality [6].

Inflammation is a common physiological process in many diseases that involves tissue damage and is often followed by pain [7]. Inflammation plays a major role in UTIs due to continuous exposure to noxious stimuli in the urine [8]. The protein complex NF- $\kappa B$ is a cytokine implicated in several inflammatory diseases, such as rheumatoid arthritis and inflammatory bowel disease. In this sense,
$\mathrm{NF}-\kappa \mathrm{B}$ cytokine is involved in kidney inflammation caused by UTIs [9].

In response to different cellular stimuli, NF- $K B$ plays a complex role in different cell types and different disease stages [10]. NF- $\kappa B$ is activated during infection and promotes the transcription of inflammatory cytokines such as TNF- $\alpha$ and IL-6 [4] that are overexpressed in bladder infections [11]. Another factor to control during an infection is the contact with microorganisms, such as bacteria, fungi, viruses, and parasites. During infection, TLRs detect the presence of bacterial components and activate macrophages that produce a series of proinflammatory cytokines (e. g., TNF- $\alpha$, IL-1 $\beta$, IL-6) that act as a defensive response against the existence of pathogens [12].

Based on the above, the treatment of UTIs can be facilitated by natural products with medicinal properties [13]. Many studies have been conducted on the treatment of urinary problems using natural products with antibacterial and anti-inflammatory action [14]. These medicinal properties can be attributed to the bioactive phytochemical constituents of various chemical families such as alkaloids, essential oils, flavonoids, tannins, diterpenes, and phenolic compounds $[14,15]$.

In this context, the Buddleja genus has been used in traditional Chinese medicine for its anti-inflammatory properties [16]. Within this genus, Buddleja coriacea Remy, known as "Kiswara or Quishuar" and belonging to the Loganiaceae family, is native to Bolivia and has been traditionally used in the form of an infusion for the treatment of ulcers, stomach pain, liver problems, urinary tract inflammation, and rheumatism [17-19]. The $B$. coriacea species has been reported to contain flavonoid glycosides, tannins, alkaloids, and diterpenes [20]. Regarding the pharmacological activities of this plant species, it has been reported that the DCM/hydroalcoholic and hydroalcoholic extracts have presented anti-inflammatory activity [20].

This manuscript aims to provide a scientific support for the traditional use of $B$. coriacea as a remedy for UTI treatment. For this purpose, a bioguided phytochemical study has been carried out to identify those compounds present in the aqueous extract of $B$. coriacea with antibacterial and anti-inflammatory activities.

Determination of the antibacterial capacity of the aqueous extract, subextracts, fractions, and compounds of isolates of $B$. coriacea was carried out against K. pneumoniae, Proteus mirabilis, Pseudomonas aeruginosa, and Serratia marcescens bacteria. On the other hand, for the determination of the anti-inflammatory capacity has been determined by measuring the inhibition of NF- $\kappa$ B production in the RM-2 (mouse prostate cell) and MM14.Ov (mouse ovary cell) cell lines.

\section{Results}

An aqueous extract was prepared from dry leaves of $B$. coriacea in order to reproduce the traditional use of the plant species [18]. Subsequently, from this aqueous extract, other subextracts were made in solvents of different polarity to study which compounds are responsible for its medicinal potential. In order to know the presence of natural metabolites and the complexity of the initial aqueous extract and subextracts, NMR spectroscopy was used. 
The evaluation of the initial aqueous extract revealed a series of aromatic signals with low intensity at around $\delta_{\mathrm{H}}$ 6.0-8.0 ppm that indicate the possible presence of compounds containing aromatic rings such as polyphenolic compounds, flavonoids, or alkaloids. Likewise, the presence of a large group of signals between $\delta_{\mathrm{H}}$ 0-4.0 ppm (aliphatic region) was observed, which may correspond to protons close to alcohols, ethers, or ketones or the presence of aliphatic chains or essential oils ( $\triangleright$ Fig. 1).

The ${ }^{1} \mathrm{H}$ NMR spectrum of the HEX subextract showed a pattern of aromatic compounds. Around $\delta_{H} 7.0$ ppm and $\delta_{H} 5.5$ ppm, signals of aromatic and vinyl hydrogens were found. Signals were observed at $\delta_{\mathrm{H}} 3.8 \mathrm{ppm}$, corresponding to neighbouring hydrogens to a heteroatom such as $\mathrm{N}-\mathrm{CH}_{3}$ or $\mathrm{O}-\mathrm{CH}_{3}$. Finally, around 1.3-0.9 ppm, typical aliphatic signals of simple hydrocarbons were observed that did not overlap with the HEX solvent ( $\vee$ Fig. 1).

Analysing the spectra of the methanolic subextract, we observed that a group of low intensity signals appeared between $\delta_{\mathrm{H}}$ 6.7-7.5 ppm, corresponding to aromatic signals. Likewise, signals at $\delta_{H} 5.08-5.36 \mathrm{ppm}$ (minisignals) corresponding to the presence of an olefinic bond were observed ( $\vee$ Fig. 1 ).

In addition, the study carried out by ${ }^{1} \mathrm{H}$ NMR together with the polarity of the used solvents allowed to affirm, based on the ob- served signals, that the HEX subextract contains more free structures, while the methanolic extract contains more molecules linked to sugars since the signals between $\delta_{\mathrm{H}}$ 2.0-4.0 ppm are more intense, which correspond to flavonoid glycosides.

Next, a comparison was made between the spectra of the HEX subextract and the three compounds isolated from it, observing how all the signals present in the compounds are also found in the subextract, although these are of less intensity and are not well defined since the subextract is a complex mixture of compounds (॰ Fig. 2).

Regarding the antibacterial capacity, the HEX subextract showed an MIC on the K. pneumoniae, P. mirabilis, P. aeruginosa, and S. marcescens strains of $37.51-37.92 \mu \mathrm{g} / \mathrm{mL}$. These results were better (statistically significant, ${ }^{* * *} \mathrm{p}<0.001$ ) than those of the aqueous extract and the other subextracts of $B$. coriacea ( $\triangleright$ Table 1 ).

These results were confirmed by the ZI assay where the HEX subextract showed a ZI of 33.39-33.90 mm, which was better (statistically significant, $\left.{ }^{* * *} \mathrm{p}<0.001\right)$ than the values of the aqueous extract and the other $B$. coriacea subextracts ( $\triangleright$ Table 2 ).

Concerning the cytotoxicity of the $B$. coriacea extracts, the results showed that the initial aqueous extract $\left(C_{50}=91.31-93.86 \mu \mathrm{g} / \mathrm{mL}\right)$ was less cytotoxic ( ${ }^{n s} p=0.074$ ) than the negative control (untreated

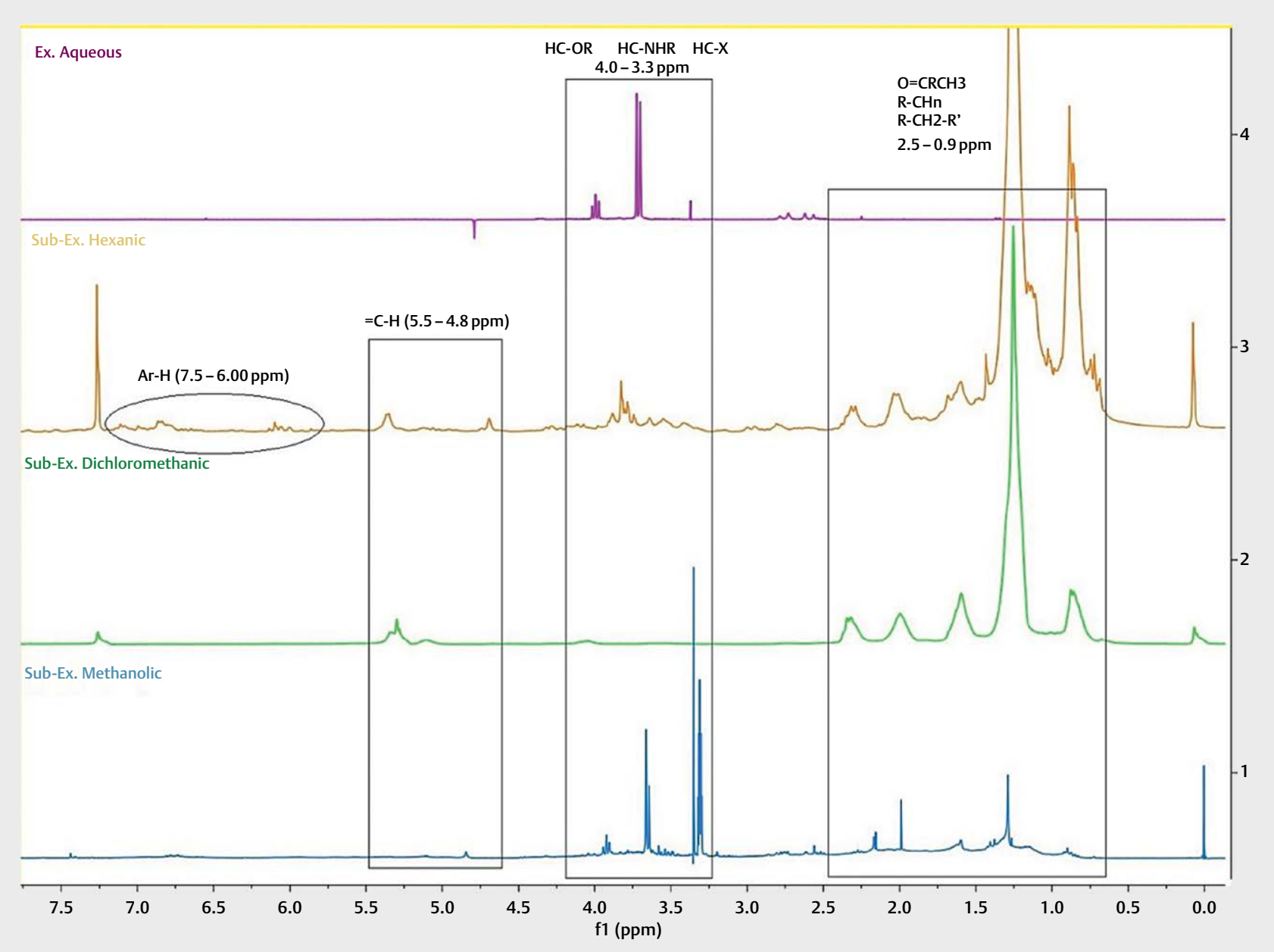

Fig. 1 Comparison of ${ }^{1} \mathrm{H}$ NMR spectra of the aqueous extract and subextracts of $B$. coriacea. 


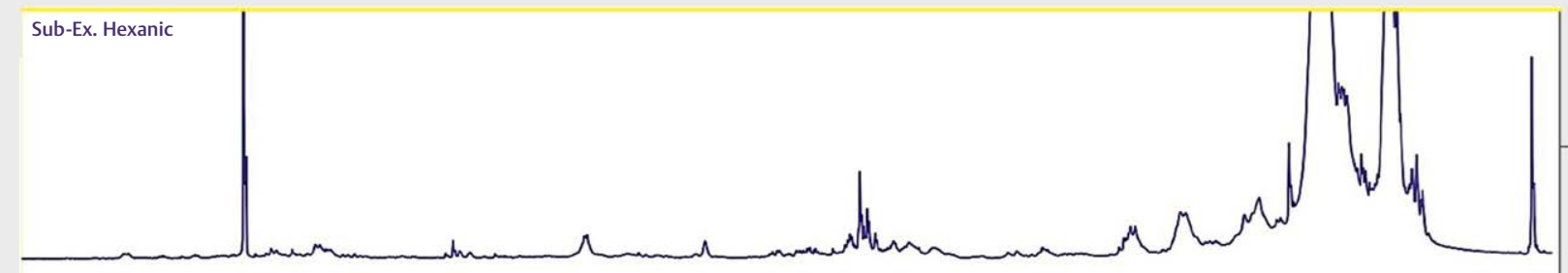

Compound 1

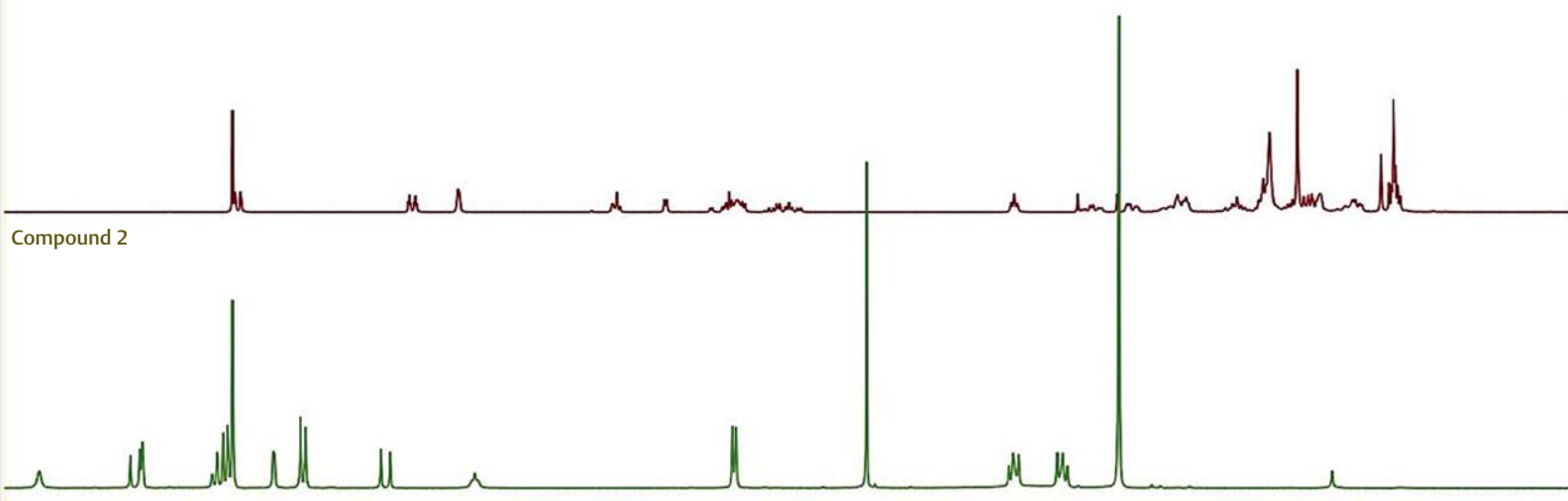

Compound 3

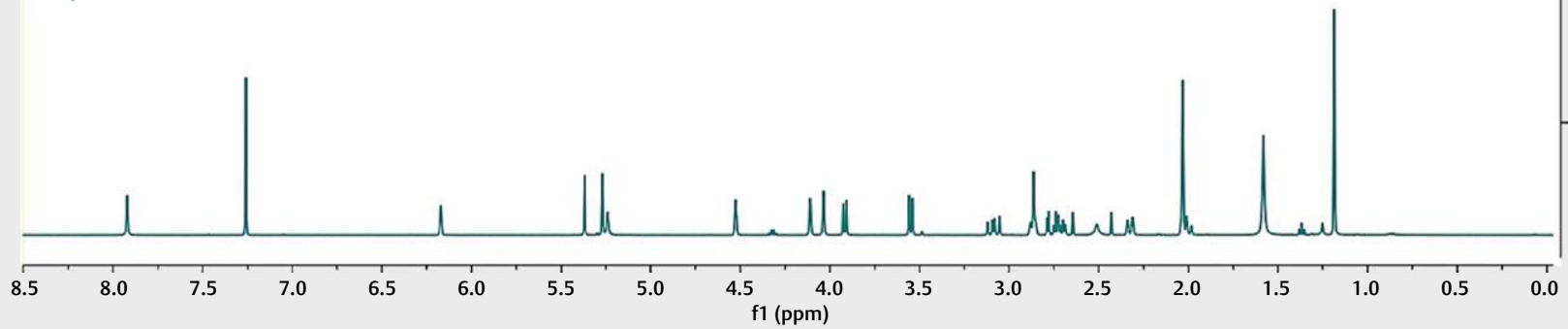

- Fig. 2 Comparison of ${ }^{1} \mathrm{H}$ NMR spectra of the HEX subextract and the isolated compounds of $B$. coriacea.

cells) in all cell lines (RM-2 and MM14.Ov). This result supports the traditional use of an aqueous infusion. Additionally, the HEX subex$\operatorname{tract}\left(\mathrm{CC}_{50}=86.13-86.73 \mu \mathrm{g} / \mathrm{mL}\right)$ was less cytotoxic $(\mathrm{p}=0.0637)$ than the negative control (untreated cells) ( $\triangleright$ Table 3). Finally, the DCM and $\mathrm{MeOH}$ subextracts were discarded for subsequent fractionation because they presented statistically significant higher cytotoxicity $\left({ }^{* * *} \mathrm{p}<0.001\right)$ than the negative control (untreated cells).

Regarding the anti-inflammatory capacity, the results showed that the HEX subextract $\left(\mathrm{IC}_{50}=35.29-36.06 \mu \mathrm{g} / \mathrm{mL}\right)$ presented a higher inhibitory activity of the production of NF- $K B\left({ }^{* * *} \mathrm{p}<0.001\right)$ than the aqueous extract and the other subextracts of $B$. coriacea ( Table 4).

In relation to the antibacterial capacity of the fractions obtained from the HEX subextract, fractions F3 and F4 showed an MIC of $30.06-30.25$ and $30.01-30.52 \mu \mathrm{g} / \mathrm{mL}$, respectively (Table $1 \mathrm{~S}$, Supporting Information) and values of $\mathrm{ZI}$ of 34.03-34.21 and 35.16$35.85 \mathrm{~mm}$, respectively (Table $2 \mathrm{~S}$, Supporting Information). These values were better $\left({ }^{* *} \mathrm{p}<0.05\right)$ than those of the other fractions. Regarding the antibacterial activity of the $\mathbf{F} \mathbf{1}$ fraction, it did not present statistically significant differences ( $\left.{ }^{\left({ }^{n} p\right.} p=0.065\right)$ when compared to the other fractions.
On the other hand, regarding the cytotoxicity of the fractions obtained from the HEX subextract (Table 3S, Supporting Information), a trend of increasing cytotoxicity was observed as the fractionation proceeded, the first fractions hardly showed any cytotoxicity while the last fractions turned out to be much more cytotoxic. In this sense, the fractions that have not shown a statistically significant higher cytotoxicity ( ${ }^{\mathrm{ns}} \mathrm{p}=0.073$ ) than the negative control (untreated cells) in the LDH assay were $\mathbf{F 1}\left(\mathrm{CC}_{50}=86.77-86.95 \mu \mathrm{g} /\right.$ $\mathrm{mL}), \mathbf{F 3}\left(\mathrm{CC}_{50}=81.57-81.66 \mu \mathrm{g} / \mathrm{mL}\right)$, and F4 $\left(\mathrm{CC}_{50}=80.14-\right.$ $81.11 \mu \mathrm{g} / \mathrm{mL})$.

Finally, the anti-inflammatory capacity of the fractions obtained from the HEX subextract are shown in Table 4S, Supporting Information, observing that fractions $\mathbf{F} 3\left(\mathrm{IC}_{50}=30.75-31.44 \mu \mathrm{g} / \mathrm{mL}\right)$ and F4 $\left(\mathrm{IC}_{50}=30.17-30.41 \mu \mathrm{g} / \mathrm{mL}\right)$ presented higher inhibitory activities of the production of NF- $\kappa$ B in all cell lines than the other fractions ( $\left.{ }^{* * *} \mathrm{p}<0.001\right)$. Regarding fraction $\mathbf{F 1}\left(\mathrm{IC}_{50}=39.33-39.68 \mu \mathrm{g} /\right.$ $\mathrm{mL}$ ), although it presented an inhibitory activity of NF- $\kappa \mathrm{B}$, this was not higher (not statistically significant, $\mathrm{p}=0.0246$ ) when compared to the other fractions.

Considering these results, we can affirm that the fractions of the HEX subextract are safe for humans and that they present anti-in- 
- Table 1 Minimum inhibitory concentration (MIC) of ${ }^{\text {B. coriacea }}$ extract and subextracts against different strains of bacteria.

\begin{tabular}{|c|c|c|c|c|}
\hline \multirow[t]{2}{*}{ Extracts } & \multicolumn{4}{|c|}{ MIC $(\mu \mathrm{g} / \mathrm{mL})$ at $48 \mathrm{~h}(\mathrm{Cl} 95 \%, \mathrm{R} 2)$} \\
\hline & $\begin{array}{l}\text { K. } \\
\text { pneumo- } \\
\text { niae }\end{array}$ & $\begin{array}{l}P . \\
\text { mirabilis }\end{array}$ & $\begin{array}{l}P . \\
\text { aerugi- } \\
\text { nosa }\end{array}$ & $\begin{array}{l}\text { S. } \\
\text { marces- } \\
\text { cens }\end{array}$ \\
\hline Ofloxacin & $\begin{array}{l}10.01 \\
(5.09 \text { to } \\
15.62 \text {, } \\
0.9836)\end{array}$ & $\begin{array}{l}10.01 \\
(5.28 \text { to } \\
15.18, \\
0.9599) \\
\end{array}$ & $\begin{array}{l}10.01 \\
(5.74 \text { to } \\
15.38, \\
0.9523) \\
\end{array}$ & $\begin{array}{l}10.01 \\
(5.16 \text { to } \\
15.14 \text {, } \\
0.9532) \\
\end{array}$ \\
\hline Aq extract & $\begin{array}{l}53.54 \\
(48.36 \text { to } \\
58.50, \\
0.9615)\end{array}$ & $\begin{array}{l}53.19 \\
(48.93 \text { to } \\
58.05, \\
0.9968)\end{array}$ & $\begin{array}{l}53.60 \\
(48.81 \text { to } \\
58.82 \text {, } \\
0.9825)\end{array}$ & $\begin{array}{l}53.84 \\
(48.84 \text { to } \\
58.90, \\
0.9507)\end{array}$ \\
\hline HEX subextract & $\begin{array}{l}37.55 \\
(31.84 \text { to } \\
41.61, \\
0.9528) \\
\end{array}$ & $\begin{array}{l}37.51 \\
(31.08 \text { to } \\
41.49, \\
0.9624) \\
\end{array}$ & $\begin{array}{l}37.80 \\
(31.43 \text { to } \\
41.56, \\
0.9576) \\
\end{array}$ & $\begin{array}{l}37.92 \\
(31.90 \text { to } \\
41.79, \\
0.9533)\end{array}$ \\
\hline DCM subextract & $\begin{array}{l}81.26 \\
(76.92 \text { to } \\
86.86, \\
0.9853) \\
\end{array}$ & $\begin{array}{l}81.11 \\
(76.34 \text { to } \\
86.94, \\
0.9944) \\
\end{array}$ & $\begin{array}{l}81.89 \\
(76.78 \text { to } \\
86.04, \\
0.9526) \\
\end{array}$ & $\begin{array}{l}81.95 \\
\text { (76.58 to } \\
86.31, \\
0.9649)\end{array}$ \\
\hline $\mathrm{MeOH}$ subextract & $\begin{array}{l}67.28 \\
(62.20 \text { to } \\
72.63 \\
0.9672)\end{array}$ & $\begin{array}{l}67.12 \\
(62.17 \text { to } \\
72.94 \\
0.9558)\end{array}$ & $\begin{array}{l}67.40 \\
(62.37 \text { to } \\
72.74 \\
0.9964)\end{array}$ & $\begin{array}{l}67.51 \\
(62.36 \text { to } \\
72.21, \\
0.9529)\end{array}$ \\
\hline
\end{tabular}

MIC was calculated using Prism v9.0.0 (GraphPad Software) using nonlinear regression, dose-response curves. $\mathrm{Cl} 95 \%$ : confidence interval $95 \% /$ Tukey's multiple comparisons test $\left({ }^{* * *} \mathrm{p}<0.001\right)$ flammatory activity, although it is still far from the positive control, celastrol $\left(\mathrm{IC}_{50}=3.32-3.34 \mu \mathrm{g} / \mathrm{mL}\right)$. In this sense, fractions F1, F3, and $\mathbf{F} 4$ were selected for their better antibacterial and anti-inflammatory activities and lower cytotoxicity, focusing on the subsequent isolation and purification of the compounds.

Subsequently, the chromatographic separation of fraction F1 (obtained from the HEX subextract) was carried out, obtaining a total of six subractions (F1a-F1f), with fraction F1f (compound $\mathbf{1}$ ) being the most active (Tables 5S-8S, Supporting Information). Likewise, the chromatographic purification of F3 and F4 (obtained from the HEX subextract) was carried out, obtaining five and four subfractions, respectively. Subfractions F3b (compound 2) (Tables 9S-12S, Supporting Information) and F4c (compound 3) (Tables 13S-16S, Supporting Information) were the most active.

The isolated compounds were identified as ( $4 \mathrm{aR}, 4 \mathrm{bS}, 5 \mathrm{~S}, 6 \mathrm{aS}, 6 \mathrm{bS}$, 9aR, 10aS, 10bS)-6b-glycoloyl-5-hydroxy-4a,6a-dimethyl-8-propyl-4a,4b,5,6,6a,6b,9a,10,10a,10b,11,12-dodecahydro-2H-naphtho $\left[2^{\prime}, 1^{\prime}: 4,5\right]$ indeno [1,2-d][1, 3] dioxol-2-one (1), 3-[3-(2dimethylaminoethyl)-1H-indol-5-yl]- $N$-(4-methoxybenzyl) acrylamide (2), and $(1 \beta, 11 \beta, 12 \alpha)-1,11,12$-trihydroxy-11,20epoxypicrasa-3,13(21)-diene-2,16-dione (3) (> Fig. 3). Compounds 1 and $\mathbf{2}$ were described as synthesis products by Ryrfeld et al. [21]. and Barf et al. [22], respectively. However, there are no reports on their chemical characterisation. Finally, in relation to compound 3, it has been isolated from different plant species, such as Ailanthus altissima[23] and Eurycoma longifolia[24].
- Table 2 In vitro culture plates (agar cup plate method) of $B$. coriacea extract and subextracts showing the zone of inhibition (ZI) concentration against different strains of bacteria.

\begin{tabular}{|c|c|c|c|c|}
\hline \multirow[t]{2}{*}{ Extracts } & \multicolumn{4}{|c|}{$\mathrm{ZI}(\mathrm{mm})$ at $48 \mathrm{~h}(\mathrm{Cl} 95 \%, \mathrm{R} 2)$} \\
\hline & $\begin{array}{l}\text { K. } \\
\text { pneumo- } \\
\text { nige }\end{array}$ & $\begin{array}{l}P . \\
\text { mirabilis }\end{array}$ & $\begin{array}{l}\text { P. } \\
\text { aerugi- } \\
\text { nosa }\end{array}$ & $\begin{array}{l}\text { S. } \\
\text { marces- } \\
\text { cens }\end{array}$ \\
\hline Ofloxacin & $\begin{array}{l}27.58 \\
(22.92 \text { to } \\
32.71, \\
0.9833) \\
\end{array}$ & $\begin{array}{l}27.98 \\
(22.89 \text { to } \\
32.88, \\
0.9593) \\
\end{array}$ & $\begin{array}{l}27.58 \\
(22.65 \text { to } \\
32.93, \\
0.9919) \\
\end{array}$ & $\begin{array}{l}27.50 \\
(22.89 \text { to } \\
32.81, \\
0.9991)\end{array}$ \\
\hline Aq extract & $\begin{array}{l}64.30 \\
(59.68 \text { to } \\
69.42, \\
0.9929)\end{array}$ & $\begin{array}{l}64.55 \\
(59.10 \text { to } \\
69.93 \text {, } \\
0.9556)\end{array}$ & $\begin{array}{l}64.17 \\
(59.93 \text { to } \\
69.43 \text {, } \\
0.9663)\end{array}$ & $\begin{array}{l}64.14 \\
(59.43 \text { to } \\
69.34 \text {, } \\
0.9668)\end{array}$ \\
\hline HEX subextract & $\begin{array}{l}33.53 \\
(28.92 \text { to } \\
38.35, \\
0.9828)\end{array}$ & $\begin{array}{l}33.90 \\
(28.21 \text { to } \\
38.23 \text {, } \\
0.9949)\end{array}$ & $\begin{array}{l}33.50 \\
(28.52 \text { to } \\
38.90, \\
0.9748)\end{array}$ & $\begin{array}{l}33.39 \\
(28.50 \text { to } \\
38.90, \\
0.9743)\end{array}$ \\
\hline DCM subextract & $\begin{array}{l}85.88 \\
(80.50 \text { to } \\
90.64, \\
0.9553)\end{array}$ & $\begin{array}{l}85.89 \\
(80.97 \text { to } \\
90.90 \text {, } \\
0.9801)\end{array}$ & $\begin{array}{l}85.61 \\
(80.67 \text { to } \\
90.55, \\
0.9625)\end{array}$ & $\begin{array}{l}85.06 \\
(80.86 \text { to } \\
90.31, \\
0.9657)\end{array}$ \\
\hline $\mathrm{MeOH}$ subextract & $\begin{array}{l}81.17 \\
(76.55 \text { to } \\
86.98, \\
0.9948)\end{array}$ & $\begin{array}{l}81.91 \\
(76.51 \text { to } \\
86.06, \\
0.9714)\end{array}$ & $\begin{array}{l}81.12 \\
(76.03 \text { to } \\
86.88, \\
0.9711)\end{array}$ & $\begin{array}{l}81.10 \\
(76.58 \text { to } \\
86.79, \\
0.9713)\end{array}$ \\
\hline \multicolumn{5}{|c|}{$\begin{array}{l}\mathrm{IC}_{50} \text { values of the ZI was calculated using Prism v9.0.0 (GraphPad Software) } \\
\text { using nonlinear regression, dose-response curves. } \mathrm{Cl} 95 \% \text { : confidence } \\
\left.\text { interval } 95 \% / \text { Tukey's multiple comparisons test ( }{ }^{* * *} \mathrm{P}<0.001\right)\end{array}$} \\
\hline
\end{tabular}

Regarding antibacterial activity, the MIC assay showed MIC values of 11.64-11.81 (compound 1), 0.17-0.19 (compound 2), and $0.34-0.36 \mu \mathrm{M}$ (compound 3). The compounds obtained showed statistically significant higher antibacterial activity $\left({ }^{* * *} \mathrm{p}<0.001\right)$ compared to the positive control (ofloxacin, $I C_{50}=27.58-27.65 \mu \mathrm{M}$ ) (> Fig. 4).

However, in the $\mathrm{ZI}$ assay, no statistically significant difference $(p=0.0869)$ was observed between the three compounds when compared to the positive control (ofloxacin, $\mathrm{ZI}=23.26-24.10 \mathrm{~mm}$ ) in K. pneumoniae, P. mirabilis, $P$. aeruginosa, and $S$. marcescens bacteria ( $\triangleright$ Fig. 5).

In relation to the determination of the cytotoxicity of the compounds, $>$ Table 5 shows that compound $\mathbf{1}\left(C_{50}=88.44-89.24 \mu \mathrm{M}\right)$ did not present more cytotoxicity $(p=0.0586)$ than the negative control (untreated cells). Although compounds $2\left(\mathrm{CC}_{50}=69.51-\right.$ $70.28 \mu \mathrm{M})$ and $3\left(\mathrm{CC}_{50}=53.95-55.16 \mu \mathrm{M}\right)$ showed cytotoxicity when compared to the negative control; these cytotoxicity values were lower than the positive control ( $\left.\mathrm{ACT}, \mathrm{CC}_{50}=0.008 \mu \mathrm{M}\right)$

Regarding anti-inflammatory activity, compounds $\mathbf{2}\left(\mathrm{IC}_{50}=\right.$ $0.15-0.16 \mu \mathrm{M})$ and $3\left(\mathrm{IC}_{50}=0.33-0.36 \mu \mathrm{M}\right)$ showed an inhibitory capacity of NF- $\kappa$ B production that was higher (statistically significant, ${ }^{* * *} \mathrm{p}<0.001$ ) than that of the positive control (celastrol, $\left.\mathrm{IC}_{50}=7.41 \mu \mathrm{M}\right)$. Regarding compound $\mathbf{1}\left(\mathrm{IC}_{50}=11.25-11.34 \mu \mathrm{M}\right)$, its inhibitory activity against the production of NF- $k$ B was similar to the positive control $(p=0.0865)$ ( $\triangleright$ Fig. 6). 
- Table $3 \mathrm{CC}_{50}$ values of the LDH (cytotoxicity) assays calculated for the extract and subextracts from $B$. coriacea.

\begin{tabular}{|c|c|c|}
\hline \multirow[t]{2}{*}{ Extracts } & \multicolumn{2}{|c|}{ Cytotoxicity $\left(\mathrm{CC}_{50} \mu \mathrm{g} / \mathrm{mL}\right)$ at $48 \mathrm{~h}(\mathrm{Cl} 95 \%, \mathrm{R} 2)$} \\
\hline & RM-2 & MM14.0v \\
\hline Untreated cells & $\begin{array}{l}97.92(92.48 \text { to } 102.53, \\
0.9454)\end{array}$ & $\begin{array}{l}98.35 \text { (93.70 to } 103.09, \\
0.9901)\end{array}$ \\
\hline DMSO & $\begin{array}{l}20.15 \text { (15.29 to } 25.18 \\
0.9759)\end{array}$ & $\begin{array}{l}20.19(15.44 \text { to } 25.80, \\
0.9872)\end{array}$ \\
\hline Actinomycin D & $\begin{array}{l}0.01(-3.991 \text { to } 3.357 \\
0.9503)\end{array}$ & $\begin{array}{l}0.01(-3.725 \text { to } 3.233 \\
0.9844)\end{array}$ \\
\hline Aq extract & $\begin{array}{l}91.31(86.45 \text { to } 96.88, \\
0.9576)\end{array}$ & $\begin{array}{l}93.86 \text { (88.45 to } 98.48 \text {, } \\
0.9994)\end{array}$ \\
\hline HEX subextract & $\begin{array}{l}86.13(81.89 \text { to } 91.94 \text {, } \\
0.9891)\end{array}$ & $\begin{array}{l}86.73(81.47 \text { to } 91.58, \\
0.9932)\end{array}$ \\
\hline DCM subextract & $\begin{array}{l}77.71 \text { (72.78 to } 82.97 \text {, } \\
0.9765)\end{array}$ & $\begin{array}{l}79.37 \text { (74.23 to } 84.88, \\
0.9659)\end{array}$ \\
\hline $\mathrm{MeOH}$ subextract & $\begin{array}{l}56.68 \text { (51.34 to 61.07, } \\
0.9986)\end{array}$ & $\begin{array}{l}58.56(53.55 \text { to } 63.85 \\
0.9712)\end{array}$ \\
\hline
\end{tabular}

$\mathrm{CC}_{50}$ was calculated using Prism v9.0.0 (GraphPad Software) using nonlinear regression, dose-response curves. Cl $95 \%$ : confidence interval $95 \% /$ Tukey's multiple comparisons test $\left({ }^{* * *} \mathrm{p}<0.001\right)$

- Table $4 \quad \mathrm{IC}_{50}$ values of the inhibition of NF- $\mathrm{KB}$ production calculated for the extract and subextracts from $B$. coriacea.

\begin{tabular}{|c|c|c|}
\hline \multirow[t]{2}{*}{ Extracts } & \multicolumn{2}{|c|}{$\begin{array}{l}\text { Inhibition of NF- } \mathrm{KB} \text { production }\left(\mathrm{IC}_{50} \mu \mathrm{g} / \mathrm{mL}\right) \text { at } \\
48 \mathrm{~h}(\mathrm{Cl} 95 \%, \mathrm{R} 2)\end{array}$} \\
\hline & RM-2 & MM14.0v \\
\hline Untreated cells & $\begin{array}{l}19.72(14.68 \text { to } 24.87, \\
0.9647)\end{array}$ & $\begin{array}{l}19.84(14.45 \text { to } 24.64, \\
0.9984)\end{array}$ \\
\hline Celastrol & $\begin{array}{l}3.33(-2.23 \text { to } 8.32 \\
0.9888)\end{array}$ & $\begin{array}{l}3.34(-2.47 \text { to } 8.90 \\
0.9868)\end{array}$ \\
\hline Aq extract & $\begin{array}{l}53.27(48.93 \text { to } 58.78, \\
0.9946)\end{array}$ & $\begin{array}{l}54.16(49.14 \text { to } 59.35, \\
0.9674)\end{array}$ \\
\hline HEX subextract & $\begin{array}{l}35.29 \text { (30.93 to } 40.47 \text {, } \\
0.9968)\end{array}$ & $\begin{array}{l}36.06(31.34 \text { to } 41.44, \\
0.9644)\end{array}$ \\
\hline DCM subextract & $\begin{array}{l}90.72(85.05 \text { to } 95.55 \\
0.9937)\end{array}$ & $\begin{array}{l}90.76(85.18 \text { to } 95.38, \\
0.9938)\end{array}$ \\
\hline $\mathrm{MeOH}$ subextract & $\begin{array}{l}66.79(61.07 \text { to } 71.35 \\
0.9563)\end{array}$ & $\begin{array}{l}67.04(62.17 \text { to } 72.05 \\
0.9789)\end{array}$ \\
\hline
\end{tabular}

$\mathrm{IC}_{50}$ was calculated using Prism v9.0.0 (GraphPad Software) using nonlinear regression, dose-response curves. $\mathrm{Cl} 95 \%$ : confidence interval $95 \% /$ Tukey's multiple comparisons test $\left({ }^{* * *} \mathrm{p}<0.001\right)$

\section{Discussion}

NMR spectroscopy has recently emerged as a very powerful and versatile tool for the identification of compounds in plant extracts $[25,26]$. Unlike the most widely used characterisation methods, such as chromatography, NMR allows investigations to be carried out both in solids and in solution. Furthermore, in recent decades, NMR hardware, computer technology, and experimental design have been developed simultaneously, thus producing a modern generation of NMR spectrometers capable of probing complex structures. This has resulted in substantial improvements in spectral data processing and visualisation [27]. In this sense, we were able to identify the presence of different compounds in the extracts of $B$. coriacea by means of ${ }^{1} \mathrm{H}$ NMR spectroscopy, focusing on those that had a higher concentration, which were $(4 a \mathrm{R}, 4 \mathrm{bS}, 5 \mathrm{~S}, 6 \mathrm{aS}, 6 \mathrm{bS}$, 9aR,10aS, 10bS)-6b-glycoloyl-5-hydroxy-4a,6a-dimethyl-8-propyl-4a,4b,5,6,6a,6b,9a, 10,10a,10b, 11,12-dodecahydro-2H-naphtho $\left[2^{\prime}, 1^{\prime}: 4,5\right]$ indeno [1,2-d][1, 3] dioxol-2-one (1), 3-[3-(2dimethylaminoethyl)-1H-indol-5-yl]-N-(4-methoxybenzyl) acrylamide (2), and $(1 \beta, 11 \beta, 12 \alpha)$-1,11,12-trihydroxy-11,20-epoxypicrasa3,13(21)-diene-2,16-dione (3).

Regarding the antibacterial activity of $B$. coriacea, there are no previous reports, however, there are reports on the antibacterial activity of other species of the genus Buddleja, e. g., the MeOH extract of Buddleja saligna showed an MIC of $5 \mathrm{mg} / \mathrm{mL}$ against $K$. pneumoniae, $P$. aeruginosa, and $S$. marcescens. When comparing this to our results, we can confirm the antibacterial potential of the Buddleja species against gram-negative bacteria. Moreover, we can also indicate that the HEX subextract of $B$. coriacea is more active than the MeOH extract of $B$. saligna[28]. Likewise, there are reports that indicate that UTIs are usually caused by gram-negative bacteria, which tend to become multiresistant to conventional antibiotics $[29,30]$, thus confirming the importance of $B$. coriacea extracts as an alternative treatment.

Moreover, although no reports were found on the cytotoxicity of the $B$. coriacea species, it was found that other species of the genus Buddleja presented cytotoxicity, e. g., the aqueous extract of Buddleja globosa presented cytotoxicity at concentrations higher than $50 \mu \mathrm{g} / \mathrm{mL}$ [31]. Analysing our results, the extracts obtained from $B$. coriacea were less cytotxic compared to other extracts from other Buddleja species.

On the other hand, previous studies have shown that the hydroalcoholic and DCM/hydroalcoholic extracts of $B$. coriacea presented anti-inflammatory activity (inhibition of the production of COX-2) in vivo in a range of concentrations around $3 \mathrm{~g} / \mathrm{kg}$ b.w. [20].

In our study, in vitro assays of the HEX subextract showed that showed what? after their production of NF- $\kappa \mathrm{B}$ is inhibited in the RM-2 and MM14.Ov cell lines. In addition, the use of solvents of different polarity allowed for evaluating compounds of a different nature present in the initial aqueous extract, indicating that in the case of the HEX subextract, there is a higher relationship between its anti-inflammatory activity and its cytotoxicity. For this reason, the HEX subextract was fractionated using HEX/AcOEt as the mobile phase, producing seven fractions that were subjected to antibacterial, cytotoxicity, and anti-inflammatory assays.

In relation to the antibacterial activity of the isolated compounds, results on compound 1 contradict previous studies. Wang et al. [32] reported that compound 1 suppresses the lung antibacterial defence, increasing the infection caused by $P$. aeruginosa. In our study, compound $\mathbf{1}$ has been reported to have antibacterial activity against gram-negative bacteria such as $E$. coli or $P$. aeruginosa in a concentration range of $0.01-100 \mu \mathrm{g} / \mathrm{mL}$ [33] and against grampositive bacteria such as $S$. aureus in a concentration range of 16$2000 \mu \mathrm{g} / 200 \mu \mathrm{L}$. Thus, these results obtained confirm the antibacterial properties of compound $\mathbf{1}$ against gram-negative bacteria, contradicting the results of Wang et al.

Regarding the antibacterial activity of compounds $\mathbf{2}$ and $\mathbf{3}$, there are no previous studies. However, the three compounds, especially $\mathbf{2}$ and 3, have shown better activity than the positive control, which is why they stand as potential alternatives for the eradication of those bacterial strains that cause chronic UTIs. 


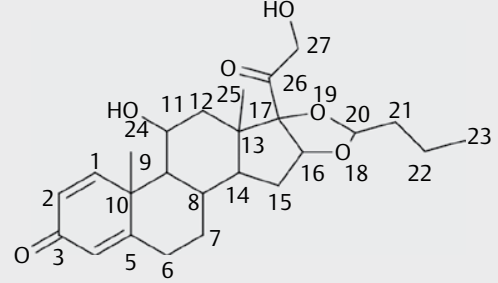

(1)<smiles>COc1ccc(CNC(=O)/C=C/c2ccc3[nH]cc(CCN(C)C)c3c2)cc1</smiles>

(2)

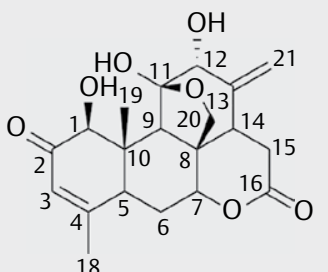

(3)

Fig. 3 The chemical structures of compounds from B. coriacea: 1 ((4aR,4bS,5S,6aS,6bS,9aR,10aS,10bS)-6b-glycoloyl-5-hydroxy-4a,6adimethyl-8-propyl-4a,4b,5,6,6a,6b,9a,10,10a,10b,11,12-dodecahydro-2H-naphtho[2',1':4,5]indeno[1,2-d] [1,3] dioxol-2-one),

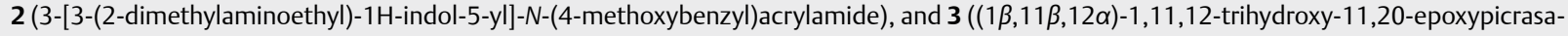
3,13(21)-diene-2,16-dione).

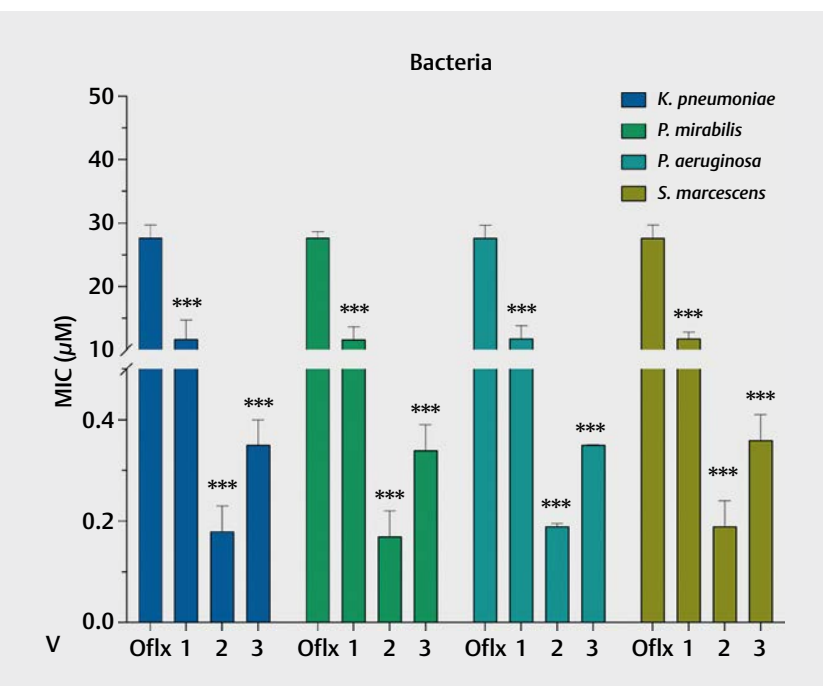

- Fig. 4 Minimum inhibitory concentration (MIC) of $B$. coriacea compounds against different strains of bacteria at $48 \mathrm{~h}$. MIC was calculated using Prism v9.0.0 (GraphPad Software) using nonlinear regression, dose-response curves. CI 95\%: confidence interval 95\%/ Tukey's multiple comparisons test ( $\left.{ }^{* * *} \mathrm{p}<0.001\right)$.

Analysing the mechanism of action based on the positive control (ofloxacin), we can indicate that the isolated compounds prevent bacterial division, which is achieved by inhibiting topoisomerases II and IV and DNA gyrase, which are necessary to complete this process [34].

Regarding the cytotoxicity activity of compounds isolated from $B$. coriacea, through an in silico study, it has been reported that compound 1 does not present significant toxicity [35]. Our results sup-

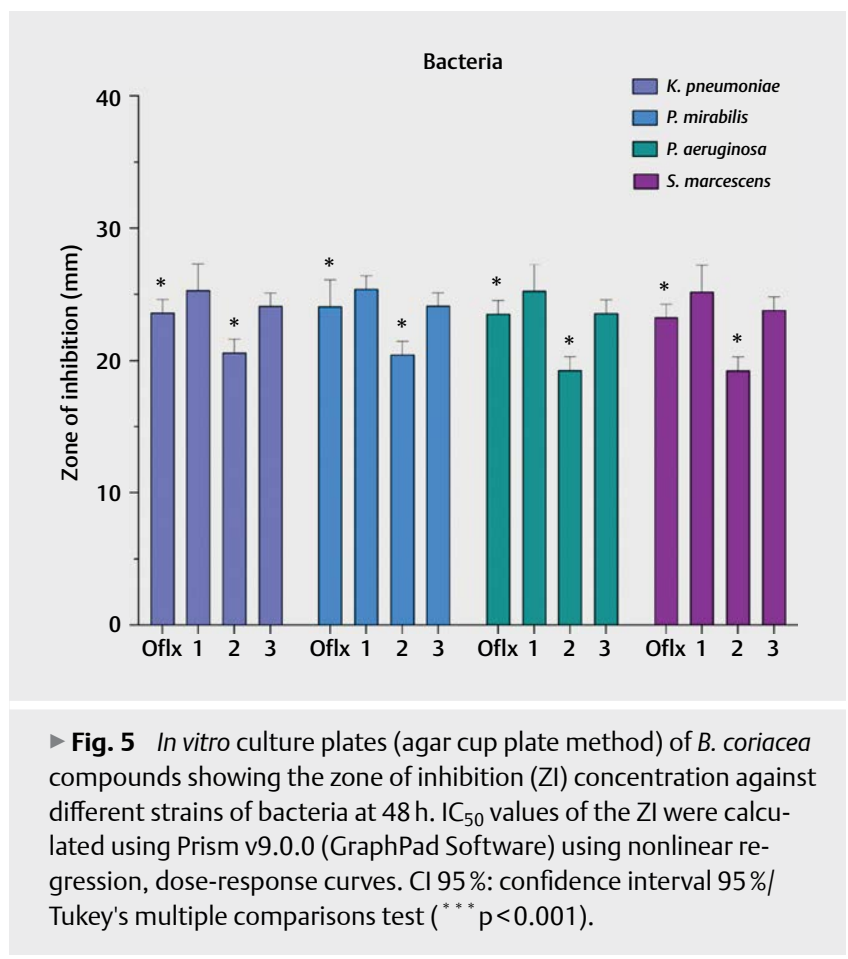

port that this compound is not cytotoxic. Concerning compound $\mathbf{2}$, no previous cytotoxicity studies have been found. However, the results obtained did not show significant cytotoxicity when compared with untreated cells $(98.45-98.97 \mu \mathrm{M})$. Finally, in relation to compound 3 , there are reports on its cytotoxicity against different tumour cell lines, with an $\mathrm{IC}_{50}$ values of $0.25-0.52 \mu \mathrm{M}$ [36]. This result is not confirmed in this study. Yet, these contradictory results 
- Table $5 \mathrm{CC}_{50}$ values of the LDH (cytotoxicity) assays calculated for the compounds from $B$. coriacea.

\begin{tabular}{|c|c|c|}
\hline \multirow[t]{2}{*}{ Compounds } & \multicolumn{2}{|c|}{ Cytotoxicity $\left(\mathrm{CC}_{50} \mu \mathrm{M}\right)$ at $48 \mathrm{~h}(\mathrm{Cl} 95 \%, \mathrm{R} 2)$} \\
\hline & BEAS-2B & IMR-90 \\
\hline Untreated cells & $\begin{array}{l}98.45(93.90 \text { to } 103.35 \text {, } \\
0.9783)\end{array}$ & $\begin{array}{l}98.97 \text { (93.75 to } 103.84 \\
0.9635)\end{array}$ \\
\hline DMSO & $\begin{array}{l}10.05 \text { ( } 5.75 \text { to } 15.08, \\
0.9634)\end{array}$ & $\begin{array}{l}10.05 \text { ( } 5.36 \text { to } 15.56 \\
0.9506)\end{array}$ \\
\hline Actinomycin D & $\begin{array}{l}0.008(-4.867 \text { to } 4.338, \\
0.9625)\end{array}$ & $\begin{array}{l}0.008 \text { (-4.642 to } 4.675 \text {, } \\
0.9764)\end{array}$ \\
\hline Compound 1 & $\begin{array}{l}88.44(83.43 \text { to } 93.39, \\
0.9897)\end{array}$ & $\begin{array}{l}89.24 \text { (84.74 to } 94.96, \\
0.9827)\end{array}$ \\
\hline Compound 2 & $\begin{array}{l}70.28 \text { (65.71 to } 75.54, \\
0.9607)\end{array}$ & $\begin{array}{l}69.51 \text { (64.94 to } 74.45 \text {, } \\
0.9522)\end{array}$ \\
\hline Compound 3 & $\begin{array}{l}53.95 \text { ( } 48.45 \text { to } 58.37 \text {, } \\
0.9856)\end{array}$ & $\begin{array}{l}55.16(50.75 \text { to } 60.46, \\
0.9562)\end{array}$ \\
\hline
\end{tabular}

$\mathrm{CC}_{50}$ was calculated using Prism v9.0.0 (GraphPad Software) using nonlinear regression, dose-response curves. $\mathrm{Cl} 95 \%$ : confidence interval $95 \% / T u k e y ' s$ multiple comparisons test $\left({ }^{* * *} \mathrm{p}<0.001\right)$.

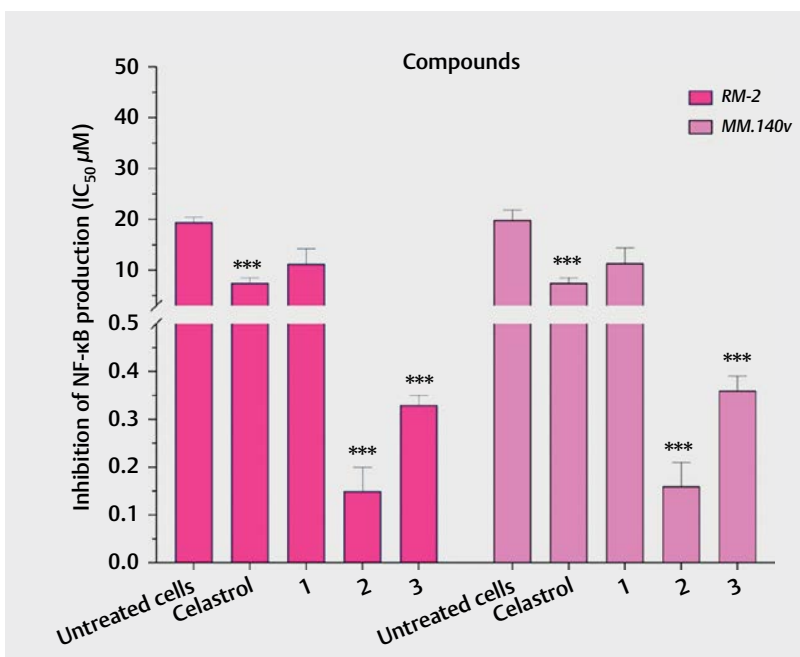

- Fig. $6 \mathrm{IC}_{50}$ values of the inhibition of NF- $\kappa \mathrm{B}$ production, calculated for the compounds from $B$. coriacea at $48 \mathrm{~h}$. $\mathrm{IC}_{50}$ was calculated using Prism v9.0.0 (GraphPad Software) using nonlinear regression, doseresponse curves. Cl 95\%: confidence interval 95\%/Tukey's multiple comparisons test $\left({ }^{* * *} \mathrm{p}<0.001\right)$.

can be due to the fact that the studies have been carried out in different cell lines [37].

Finally, regarding the anti-inflammatory activity of the isolated compounds, compound $\mathbf{1}$ is a glucocorticoid with powerful antiinflammatory effects [38] that is used to treat chronic inflammatory diseases [39]. However, although compound $\mathbf{1}$ was isolated as a mixture of diastereoisomers, they do not show significant structural differences, so the activity of both structures can be assumed to be similar. Moreover, there are previous studies on diastereoisomeric mixtures with anti-inflammatory activity [40]. It should be noted that glucocorticoids are used in the treatment of lung diseases such as asthma and COPD because they inhibit the gene ex- pression dependent on NF- $\kappa \mathrm{B}$ [33] and suppress the production of proinflammatory cytokines. [32].

On the other hand, the mechanism of action of compounds 2 and $\mathbf{3}$ on the NF- $\kappa \mathrm{B}$ pathway is unknown since there are no previous reports showing anti-inflammatory activity. A possible mechanism of action may be similar to the one of celastrol (positive control), which is based on the suppression of phosphorylation of IKK $\alpha \beta$ (it suppresses the degradation of $I_{\kappa} \beta \alpha$ and inhibits the translocation of $\mathrm{p} 65$ to the nucleus) [34]. However, this is only a hypothesis since there are no other studies that analyse the mechanism of action of the isolated compounds.

Thus, we can conclude that the isolated compounds have antiinflammatory properties. Additionally, by predicting the potential pharmacokinetic properties of the three compounds using SwisSADME, it was determined that all three compounds have high gastrointestinal absorption and are soluble. These results support the traditional use of the aqueous extract due to its pharmacokinetic properties.

From in vitro assays, it has been confirmed that the three compounds isolated from $B$. coriacea leaves have antibacterial and anti-inflammatory activities, and they are not cytotoxic, being partly responsible for the ethnopharmacological activity (treatment of urinary infections) of the plant. This is the first time that compounds 1, 2, and $\mathbf{3}$ have been studied for the treatment of UTIs due to their antibacterial and anti-inflammatory properties.

With the present work, it has been established that the isolated compounds could have potential use for the development of oral treatments for UTIs, offering an alternative to those already present on the market. In addition, the isolated compounds may be useful in the future as structures for the synthetic development of libraries of compounds that may have better activity. However, the continuation of bioguided isolation in search of new compounds cannot be ruled out, since hardly any previous studies were found that report the chemical composition of the species $B$. coriacea.

\section{Material and Methods}

\section{Bacteria, cell lines, biochemicals, and chemicals}

Gram-negative bacteria, K. pneumoniae (BAA-3079), P. mirabilis (BAA-3087), P. aeruginosa (CRM-9027), and S. marcescens (25419), were purchased from the ATCC. Animal cell lines RM-2 (CRL-3311) and MM14.Ov (CRL-6383) were purchased from the ATCC.

Cells were cultured in media DMEM (Sigma-Aldrich). FBS (Summit Biotechnology) and PBS (SAFC Biosciences, Inc.) were used as culture mediums. L-Glutamine was obtained from Applichem. Penicillin and streptomycin were purchased from Fisher Scientific. For both the cytotoxicity and activity assays, the compounds were dissolved in DMSO (Merck) at a concentration of $10 \mathrm{mM}$, while extracts and fractions were dissolved at $20 \mathrm{mg} / \mathrm{mL}$ in DMSO. The incubation condition for all cells was in an atmosphere of $95 \%$ air and $5 \% \mathrm{CO} 2$ at $37^{\circ} \mathrm{C}$.

Samples were separated by column chromatography with silica gel (20-45 $\mu \mathrm{m}$ and 40-63 $\mu \mathrm{m}$; Merck). TLC (Merck Silica gel 60- $\mathrm{F}_{254}$ plates) was used for the compounds visualisation by means of UV light [Spectroline E-Series UV lamp with one longwave (365 nm) 
and one shortwave (254 nm) tube, $230 \mathrm{~V}$ ] and/or by staining the plate with a $5 \%$ phosphomolybdic acid (Merck) solution in EtOH (Merck) followed by heat application. All organic solvents that were used for isolating the compounds were purchased from Merck.

\section{Plant material}

The aerial parts of $B$. coriacea were collected from the Pucarani town, Los Andes province, La Paz, Bolivia (16²4'13.5”S 68 ²8'37.7”W), in June 2019 , at an altitude of $3865 \mathrm{~m}$. The botanical identification was confirmed by the National Herbarium of Bolivia (No. 14021).

\section{Extraction and isolation}

The air-dried leaves $(1 \mathrm{~kg}$ ) from $B$. coriacea were extracted by decoction ( 30 min at boiling point) with $2 \mathrm{~L}$ of $\mathrm{DH}_{2} \mathrm{O}$. The resulting aqueous extract was frozen in glass containers at a temperature of $-38^{\circ} \mathrm{C}$ and then lyophilised (freeze dryer, Christ alpha 1e2 LD plus) at $-50^{\circ} \mathrm{C}$. Subsequently, $45 \mathrm{~g}$ of the aqueous extract were extracted by repeated maceration ( 3 times/24h/rt) with $500 \mathrm{~mL}$ of different solvents, increasing the polarity: HEX, DCM, and MeOH. Next, the subextracts were filtered, and the respective solvents were removed by vacuum rotary evaporation at $\mathrm{rt}\left(25^{\circ} \mathrm{C}\right)$. As a result, three subextracts of $1.38,1.77$, and $2.67 \mathrm{~g}$, respectively, were obtained.

The HEX subextract $(1.77 \mathrm{~g}$ ) was selected because it was the most active one, and was subsequently fractionated using a chromatographic column $(2 \times 30 \mathrm{~cm})$ with Si-60 Silica gel $(40-63 \mu \mathrm{m}$; Merck) as a stationary phase and a gradient of HEX/AcOEt (49:1 $\rightarrow$ 5:1) as the eluent. A total of seven fractions (F1-F7) were obtained: F1 (0.204 g), F2 (0.047g), F3 (0.114g), F4 (0.045 g), F5 (0.112g), F6 $(0.074 \mathrm{~g})$, and F7 $(0.149 \mathrm{~g})$.

Based on the biological activity data, we could then conclude that fractions F1, F3, and F4 had lower cytotoxicity. A second separation of $\mathbf{F} \mathbf{1}$ was carried out by using a chromatographic column $(1 \times 20 \mathrm{~cm})$ with Si-60 Silica gel $(40-63 \mu \mathrm{m}$; Merck) as a stationary phase and HEX/AcOEt (2:1) as the mobile phase. A total of six subfractions (F1.a-F1.f) were obtained: F1.a $(2.8 \mathrm{mg})$, F1.b $(3.9 \mathrm{mg})$, F1.c (4.7 mg), F1.d (1.1 mg), F1.e (1.8 mg), and F1.f (4.8 mg), which was compound 1 .

A third separation of $\mathbf{F} \mathbf{3}$ was carried out by using a chromatographic column $(1 \times 20 \mathrm{~cm})$ with Si-60 Silica gel $(40-63 \mu \mathrm{m}$; Merck) as the stationary phase and $\mathrm{Et}_{2} \mathrm{O} / \mathrm{DCM}(1: 6)$ as the mobile phase. A total of five subfractions (F3.a-F3.e) were obtained: F3.a (5.4 mg), F3.b (1.4 mg), which was compound 2, F3.C (1.0 mg), F3.d (3.7 mg), and F3.e (6.8 mg).

Finally, a separation on a silica gel microcolumn was carried out to separate $\mathbf{F 4}$ using DCM/AcOEt (1:2). A total of four subfractions (F4.a-F4.d) were obtained: F4.a (2.4 mg), F4.b (1.1 mg), F4.C (1.2 mg, compound 3), and F4.d (1.8 mg).

\section{NMR analysis}

NMR spectroscopy experiments were carried out on Bruker Advance DRX 300 and 500 spectrometers operating at $300 \mathrm{MHz}$, $500 \mathrm{MHz}\left({ }^{1} \mathrm{H}\right)$, or $75 \mathrm{MHz}$, and $126 \mathrm{MHz}\left({ }^{13} \mathrm{C}\right)$ with TMS as the reference solvent $\left(\delta_{\mathrm{H}} 0 \mathrm{ppm}\right)$. Spectra were calibrated by assignment of the residual solvent peak to $\delta_{\mathrm{H}} 7.26, \delta_{\mathrm{H}} 3.31$, and $\delta_{\mathrm{C}} 77.16, \delta_{\mathrm{C}} 49.00$ for $\mathrm{CDCl}_{3}$ ( $\geq 99.8 \%$; Sigma-Aldrich, CAS Number 865-49-6) and MeOD ( $\geq 99.8 \%$; Sigma-Aldrich, CAS Number 811-98-3), respec- tively. The complete assignment of protons and carbons was done by correlated ${ }^{1} \mathrm{H}-{ }^{1} \mathrm{H}$ COSY, HSQC, and HMBC spectra analysis.

\section{MS analysis}

HR-El-MS analyses were performed using a mass spectrometer with a hybrid QTOF analyser, model MAXIS II from Bruker, S.A. Samples were analysed using the electrospray ionisation technique, by direct infusion at a flow of $3 \mu \mathrm{L} / \mathrm{min}$, using $\mathrm{MeOH}$ (Merck) with $0.1 \%$ formic acid (Merck) as the ionising phase. The source parameters were as follows: end plate offset: $500 \mathrm{~V}$; capillary: 3500 ; nebuliser: 0.2 bar; dry gas: $2.0 \mathrm{~L} / \mathrm{min}$; dry temp.: $250^{\circ} \mathrm{C}$; and mass range of 50-3000 Da.

\section{Broth microdilution method}

The MIC values of the samples against the bacterial strains were determined using the microdilution method in 96-well plates following the procedure described by Apaza et al. [34]. Ofloxacin ( $\geq 98 \%$; Sigma-Aldrich, CAS Number 82419-36-1) was used as a positive control (of $10.01 \mu \mathrm{g} / \mathrm{mL}$, equivalent to $27.67 \mu \mathrm{M}$ for the compounds). Each MIC determination was carried out in triplicate.

\section{Agar well diffusion method}

Agar well diffusion method was carried out in accordance with the procedure described by Apaza et al. [41]. Ofloxacin ( $\geq 98 \%$ SigmaAldrich; CAS Number 82419-36-1) was used as a positive control (of $10.01 \mu \mathrm{g} / \mathrm{mL}$, equivalent to $27.67 \mu \mathrm{M}$ for the compounds). $\mathrm{ZI}$ of each bacterial strain was measured with a calibrated digital Vernier caliper in triplicate.

\section{Cytotoxicity assay}

The samples were tested in a panel of two cell lines (RM-2 and MM14.Ov) by means of the LDH assay in accordance with the procedure described by Apaza et al. [34]. ACT ( $\geq 95 \%$; Sigma-Aldrich, CAS Number 50-76-0) was used as a positive control at a concentration of $0.01 \mu \mathrm{g} / \mathrm{mL}$ (equivalent to $0.008 \mu \mathrm{M}$ for the compounds).

\section{Nuclear factor kappa-light-chain-enhancer of activated $B$ cells inhibition assay}

In vitro anti-inflammatory activity (NF- $\kappa$ B inhibition assay) was carried out following the procedure described by Apaza et al. [34]. Celastrol ( $\geq 98 \%$; Sigma-Aldrich, CAS Number 34157-83-0) was used as a positive control at a concentration of $3.34 \mu \mathrm{g} / \mathrm{mL}$ (equivalent to $7.41 \mu \mathrm{M}$ for the compounds).

\section{Statistical analysis}

Cytotoxic concentration $50 \%\left(\mathrm{CC}_{50}\right)$ and inhibitory concentration $50 \%\left(\mathrm{IC}_{50}\right)$ values were determined by nonlinear regression. All experiments were performed in triplicate. One-way ANOVA statistical analysis (Tukey's multiple comparisons test, ${ }^{* *} \mathrm{p}<0.05,{ }^{* * *} \mathrm{p}<0.001$ ) was performed to evaluate the significant differences among values. All analyses were performed using 1994-2020 GraphPad Prism Software LLC version 9.0.0. (86) for Mac (producer Dennis Radushev www.graphpad.com).

\section{Supporting information}

${ }^{1} \mathrm{H}$ - and ${ }^{13} \mathrm{C}$ - NMR, ${ }^{1} \mathrm{H}-{ }^{1} \mathrm{H}$ COSY, HSQC, HMQC, HMBC, and MS spectra for the different fractions assayed in this study and for the iso- 
lated compounds (Figs. 5S-33S) as well as activity data of the $B$. coriacea fractions from the different samples (Tables 1S-16S) are provided as Supporting Information.

\section{Acknowledgments}

This work was supported by the National Herbarium of Bolivia, the Fundación de la Universidad Autónoma de Madrid (FUAM).

\section{Conflict of Interest}

The authors declare they have no conflict of interest.

\section{References}

[1] Chou ST, Lo HY, Li CC, Cheng LC, Chou PC, Lee YC, Ho TY, Hsiang CY. Exploring the effect and mechanism of Hibiscus sabdariffa on urinary tract infection and experimental renal inflammation. J Ethnopharmacol 2016; 194: 617-625

[2] Grigoryan L, Trautner BW, Gupta K. Diagnosis and management of urinary tract infections in the outpatient setting: a review. J Am Med Assoc 2014; 312: 1677-1684

[3] Steenkamp V, Gouws MC, Gulumian M, Elgorashi EE, Van Staden J. Studies on antibacterial, anti-inflammatory and antioxidant activity of herbal remedies used in the treatment of benign prostatic hyperplasia and prostatitis. J Ethnopharmacol 2006; 103: 71-75

[4] Flores-Mireles AL, Walker JN, Caparon M, Hultgren SJ. Urinary tract infections: epidemiology, mechanisms of infection and treatment options. Nat Rev Microbiol 2015; 13: 269-284

[5] Karlsson M, Scherbak N, Reid G, Jass ]. Lactobacillus rhamnosus GR-1 enhances NF-kappaB activation in Escherichia coli-stimulated urinary bladder cells through TLR4. BMC Microbiol 2012; 12: 1-10

[6] Hannan T], Mysorekar IU, Hung CS, Isaacson-Schmid ML, Hultgren S]. Early severe inflammatory responses to uropathogenic $E$. coli predispose to chronic and recurrent urinary tract infection. PLoS Pathog 2010; 6: 29-30

[7] Chen L, Deng H, Cui H, Fang J, Zuo Z, Deng J, Li Y, Wang X, Zhao L. Inflammatory responses and inflammation-associated diseases in organs. Oncotarget 2018; 9: 7204-7218

[8] Purves JT, Hughes FM. Inflammasomes in the urinary tract: a disease-based review. Am J Physiol Ren Physiol 2016; 311: F653-F662

[9] Zhang $\mathrm{H}$, Sun SC. NF- $\mathrm{KB}$ in inflammation and renal diseases. Cell Biosci 2015; 5: 1-12

[10] Lawrence T. The nuclear factor NF-kappaB pathway in inflammation. Cold Spring Harb Perspect Biol 2009; 1: 1-11

[11] Grover S, Srivastava A, Lee R, Tewari AK, Te AE. Role of inflammation in bladder function and interstitial cystitis. Ther Adv Urol 2011; 3: 19-33

[12] Medzhitov R. Recognition of microorganisms and activation of the immune response. Nature 2007; 449: 819-826

[13] Das $S$. Natural therapeutics for urinary tract infections-a review. Futur ] Pharm Sci 2020; 6: 64

[14] Devi N, Rani K, Kharb P, Prasad M. Herbal Medicine for Urinary Tract Infections with the Blazing Nanotechnology. J Nanosci Nanotechnol 2021; 21: 3495-3512.
[15] Shaheen G, Akram M, Jabeen Shah SMA, Munir N, Daniyal M, Riaz M, Tahir IM, Ghauri AO, Sultana S, Zainab R, Khan M. Therapeutic potential of medicinal plants for the management of urinary tract infection: A systematic review. Clin Exp Pharmacol Physiol 2019; 46: 613-624

[16] Morales MA, Collado C, Alvarez N, Bustamante S. Fundamentación básica al uso etnomédico de Matico (Buddleja globosa Hope). Rev Fitoter 2015; 15: 37-51

[17] Bussmann RW, Paniagua Zambrana NY, Moya Huanca LA, Hart R. Changing markets - Medicinal plants in the markets of La Paz and El Alto, Bolivia. J Ethnopharmacol 2016; 193: 76-95

[18] De Lucca DM, Zalles AJ. Utasan Utjir Qollanaka. Medicinas junto a nuestra casa. La Paz, Bolivia: Agencia Española de Cooperación Internacional; 2006 pp 98

[19] Paniagua-Zambrana NY, Bussmann RW. Buddleja americana L. Buddleja coriacea J. Rémy Scrophulariaceae. In: Paniagua-Zambrana NY, Bussmann RW, editors. Ethnobotany of the Andes. Heidelberg: Springer; 2020: 385-390

[20] Siñani GB. Determinacion de la actividad antiinflamatoria en interaccion de extractos de la planta Kiswara (Buddleja coriácea Rémy) con Dexametasona, mediante los ensayos de edema plantar y auricular en modelo murino [dissertation]. La Paz: Universidad Mayor San Andres; 2009

[21] Ryrfeld Å, Tönnesson M, Nilsson E, Wikby A. Pharmacokinetic studies of a potent glucocorticoid (Budesonide) in dogs by high-performance liquid chromatography. J Steroid Biochem 1979; 10: 317-324

[22] Barf TA, de Boer P, Peroutka S], Svensson K, Ennis MD, Ghazal NB, Mcguire JC, Smith MW. 5-HT 1D receptor agonist properties of novel 2-[5-[[(trifluoromethyl) sulfonyl]oxy]indolyl]ethylamines and their use as synthetic intermediates. J Med Chem 1996; 39: 4717-4726

[23] Ishibashi M, Yoshimura S, Tsuyuki T, Takahashi T, Itai A, litaka Y. Structure Determination of Bitter Principles of Ailanthus altissima. Structures of Shinjulactones F, I, J, and K. Bull Chem Soc Jpn 1984; 57 : 2885-2892

[24] Morita H, Kishi E, Takeya K, Itokawa H, Tanaka O. New Quassinoids from the Roots of Eurycoma longifolia. Chem Lett 1990; 19: 749-752

[25] Bilia AR, Bergonzi MC, Mazzi G, Vincieri FF. NMR spectroscopy: a useful tool for characterisation of plant extracts, the case of supercritical $\mathrm{CO}_{2}$ arnica extract. J Pharm Biomed Anal 2002; 30: 321-330

[26] Deborde C, Fontaine JX, Jacob D, Botana A, Nicaise V, Richard-Forget F, Lecomte S, Decourtil C, Hamade K, Mesnard F, Moing A, Molinié R. Optimizing 1D 1H-NMR profiling of plant samples for high throughput analysis: extract preparation, standardization, automation and spectra processing. Metabolomics 2019; 15: 1-12

[27] Chauthe SK, Sharma RJ, Aqil F, Gupta RC, Singh IP. Quantitative NMR: an applicable method for quantitative analysis of medicinal plant extracts and herbal products. Phytochem Anal 2012; 23: 689-696

[28] Adedapo AA, Jimoh FO, Koduru S, Masika PJ, Afolayan AJ. Assessment of the medicinal potentials of the methanol extracts of the leaves and stems of Buddleja saligna. BMC Complement Altern Med 2009; 6: 1-8

[29] Chen CY, Chen YH, Lu PL, Lin WR, Chen TC, Lin CY. Proteus mirabilis urinary tract infection and bacteremia: risk factors, clinical presentation, and outcomes. J Microbiol Immunol Infect 2012; 45: 228-236

[30] Cristea OM, Avrămescu CS, Bălășoiu M, Popescu FD, Popescu F, Amzoiu MO. Urinary tract infection with Klebsiella pneumoniae in Patients with Chronic Kidney Disease. Curr Heal Sci J 2017; 43: 137-148

[31] Mensah AY, Sampson J, Houghton PJ, Hylands PJ, Westbrook J, Dunn M, Hughes MA, Cherry GW. Effects of Buddleja globosa leaf and its constituents relevant to wound healing. J Ethnopharmacol 2001; 77: 219-226 
[32] Wang P, Wang X, Yang X, Liu Z, Wu M, Li G. Budesonide suppresses pulmonary antibacterial host defence by down-regulating cathelicidinrelated antimicrobial peptide in allergic inflammation mice and in lung epithelial cells. BMC Immunol 2013; 14: 1-9

[33] Zhang Y, Reenstra WW, Chidekel A. Antibacterial activity of apical surface fluid from the human airway cell line Calu-3: pharmacologic alteration by corticosteroids and $\beta 2$-agonists. Am J Respir Cell Mol Biol 2001; 25: 196-202

[34] Apaza Ticona L, Rumbero Sánchez Á, Sánchez Sánchez-Corral J, Iglesias Moreno P, Ortega Domenech M. Anti-inflammatory, pro-proliferative and antimicrobial potential of the compounds isolated from Daemonorops draco (Willd.) Blume. J Ethnopharmacol 2021; 268: 113668

[35] Bououden W, Benguerba Y. Computational Quantum Chemical Study, Drug-Likeness and In Silico Cytotoxicity Evaluation of Some Steroidal Anti-Inflammatory Drugs. J Drug Deliv Ther 2020; 10: 68-74

[36] Yang XL, Yuan YL, Zhang DM, Li F, Ye WC. Shinjulactone O, a new quassinoid from the root bark of Ailanthus altissima. Nat Prod Res 2014; 28: 1432-1437
[37] Lin Z, Will Y. Evaluation of drugs with specific organ toxicities in organ-specific cell lines. Toxicol Sci 2012; 126: 114-127

[38] Barrette AM, Roberts JK, Chapin C, Egan EA, Segal MR, Oses-Prieto JA, Chand S, Burlingame AL, Ballard PL. Antiinflammatory Effects of Budesonide in Human Fetal Lung. Am J Respir Cell Mol Biol 2016; 5: 623-632

[39] Bayiha JC, Evrard B, Cataldo D, De Tullio P, Mingeot-Leclercq MP. The Budesonide-Hydroxypropyl- $\beta$-Cyclodextrin Complex Attenuates ROS Generation, IL-8 Release and Cell Death Induced by Oxidant and Inflammatory Stress. Study on A549 and A-THP-1 Cells. Molecules 2020; 25: 4882

[40] Sheridan H, Walsh J], Cogan C, Jordan M, McCabe T, Passante E, Frankish NH. Diastereoisomers of 2-benzyl-2, 3-dihydro-2-(1H-inden2-yl)-1H-inden-1-ol: potential anti-inflammatory agents. Bioorganic Med Chem Lett 2009; 19: 5927-5930

[41] Apaza Ticona L, Rumbero Sánchez Á, Gonzáles Orozco O, Ortega Domenech M. Antimicrobial compounds isolated from Tropaeolum tuberosum. Nat Prod Res 2021; 35: 4698-4702 